\title{
Antibacterial Activity of Aqueous and Methanolic Extracts of Crocus sativus Stigma and Cinnamomum cassia against Clinical Isolates of some Gram-Positive and Gram-Negative Pathogenic Bacteria
}

\author{
Najmeh Jomehpour (PhD \\ Candidate) \\ Department of Microbiology and \\ Virology, Faculty of Medicine, \\ Mashhad University of Medical \\ Sciences, Mashhad, Iran \\ Kiarash Ghazvini (PhD) \\ Antimicrobial Resistance Research \\ Center, Buali Research Institute, \\ Mashhad University of Medical \\ Sciences, Mashhad, Iran, and \\ Department of Microbiology and \\ Virology, Faculty of Medicine, \\ Mashhad University of Medical \\ Sciences, Mashhad, Iran \\ Mahshid Jomehpour (BSc) \\ Lab Sciences, Shahrood University of \\ Medical Sciences \\ Corresponding author: Najmeh \\ Jomehpour \\ Email: Jomehpourn961@mum.ac.ir \\ Tel: +98-9153314525 \\ Address: Faculty of Medicine, \\ Mashhad University of Medical \\ Sciences, Mashhad, Iran
}

Received: 26 Feb 2018

Revised: 08 Apr 2019

Accepted: 26 Apr 2018 (c) (i) (9)

This work is licensed under a Creative Commons Attribution 4.0 License.

\begin{abstract}
Background and Objectives: Medicinal and aromatic plants are sources of natural antimicrobial compounds that could be useful replacements for antibiotics. The aim of this study was to assess antimicrobial activity of Crocus sativus stigma and Cinnamomum cassia extracts against some Gram-positive and Gram-negative bacteria.

Methods: Antimicrobial activity of methanolic and aqueous extracts of the plants was tested against clinical isolates of Klebsiella pneumonia, Pseudomonas aeruginosa, Staphylococcus aureus, Escherichia coli and Enterococcus using the microdilution method. Minimal inhibitory concentration (IIC) and minimum bactericidal concentration of each extract against the mentioned bacteria were also determined.

Results: The MIC of the methanolic extract of $C$. cassia was $80 \mu \mathrm{g} / \mathrm{ml}$ against Enterococcus, K. pneumonia and E. coli. The MIC of the methanolic extract of $C$. sativus was $160 \mu \mathrm{g} / \mathrm{ml}$ against Enterococcus and S. aureus. The minimum bactericidal concentration of the methanolic extracts of $C$. sativus and C. cassia was $320 \mu \mathrm{g} / \mathrm{ml}$ against $K$. pneumonia and $160 \mu \mathrm{g} / \mathrm{ml}$ against Enterococcus.

Conclusion: The extracts of C. sativus and C. cassia exhibit promising antibacterial activities against clinical isolates of the tested bacteria. 0ur results suggest that the extract of these plants can be further exploited as potential antibacterial agents against multi-drug resistant bacteria.
\end{abstract}

Keywords: Cinnamomum aromaticum, Crocus, Anti-Bacterial Agents.

This paper should be cited as: Jomehpour N, Ghazvini GH, Jomehpour M[Antibacterial Activity of Aqueous and Methanolic Extracts of Crocus sativus Stigma and Cinnamomum cassia against Clinical Isolates of some GramPositive and Gram-Negative Pathogenic Bacteria]. mljgoums. 2019; 13(3): 31-34 


\section{INTRODUCTION}

Infections caused by pathogenic bacteria have been considered a main cause of morbidity and mortality in humans (1), particularly following the emergence and spread of multidrug-resistant bacteria which have increased the risk of treatment failure (2). Hence, it is crucial to find alternative antibacterial agents with therapeutic potential against antibiotic-resistant pathogens. The discovery and use of medicinal plants go back to prehistoric times (3). It is well-demonstrated that extract of some medicinal plants possess antibacterial, antimutagenic, antithrombotic and vasodilatory properties (4). Therefore, medicinal plants are currently investigated as a major source of natural pharmaceutically valuable drugs that could be used for treatment of human diseases (5).

Crocus sativus, commonly known as saffron crocus, is a plant species from the family Iridaceae that is native to Southern Europe but currently cultivated worldwide, predominantly in Iran, Spain, Italy and Greece (6). Saffron is the stigma of the plant, which has been used for treatment of several medical conditions, such as gastrointestinal disorders, urinary tract infections, catarrhal and malignancies (7). Cinnamon is another well-known medicinal plant that belongs to the genus Cinnamomum, family Lauraceae, which is widely distributed in China, India and Australia (8). Cinnamon cassia has been shown to have choleretic, antiulcer, antifungal, antibacterial, antiviral and anti-inflammatory properties (9). Cinnamon bark is rich in cinnamaldehyde, a highly electronegative compound that inhibits growth of microorganisms by interfering in biological processes involving electron transfer and interacting with nitrogen-containing components, e.g. proteins and nucleic acids (10). The aim of this study was to assess antimicrobial activity of $C$. sativus stigma and C. cassia extracts against some Gram-positive and Gram-negative bacteria.

\section{MATERIALS AND METHODS}

C. sativus (stigma) and C. cassia were obtained from a local herbal market in Torbate Heydariyeh and Mashhad, Iran. The plants were shade dried at room temperature. Dried plants were ground to fine powder using a homogenizer. Methanolic and aqueous extracts of the plants were obtained by soaking $5 \mathrm{~g}$ of plant powder into $50 \mathrm{~mL}$ of denatured $\mathrm{MeOH}$ (95\%) and sterile distilled water in a flask for 72 hours, respectively. The flasks were agitated daily. Stock concentrations of 100 $\mathrm{mg} / \mathrm{mL}$ of dry extracts in dimethyl sulfoxide were prepared, sterile filtered $(0.2 \mu \mathrm{m})$ and stored in darkness at $25^{\circ} \mathrm{C}$.

Clinical isolates of Gram-positive (Staphylococcus aureus, Enterococcus and Streptococcus pyogenes) and Gram-negative (Escherichia coli, Klebsiella pneumonia and Pseudomonas aeruginosa) bacteria were obtained from patients hospitalized in the Ghaem hospital, Mashhad, Iran. The bacteria were grown overnight in brain heart infusion (BHI) broth (LioFilchem, Italy) at $37^{\circ} \mathrm{C}$. After obtaining a turbidity equivalent to that of a 0.5 McFarland standard $\left(10^{8} \mathrm{CFU} / \mathrm{mL}\right)$, bacterial suspensions were adjusted with sterile saline to a concentration of $1 \times 10^{5} \mathrm{CFU} / \mathrm{ml}$.

Minimum inhibitory concentration (MIC) of the extracts against the bacteria was determined using the microdilution method as recommended by the Clinical and Laboratory Standards Institute (CLSI) (11). The MIC was defined as the lowest concentration of extract that inhibited growth of bacteria (12). The stock solutions of both extracts were diluted and transferred into first well of a 96-well plate, and serial dilutions were made to obtain concentration range of $80-320 \mu \mathrm{g} / \mathrm{ml}$. The plate was incubated at $37{ }^{\circ} \mathrm{C}$ for 24 hours in aerobic conditions. Then, $200 \mu \mathrm{l}$ of tetrazolium chloride solution $(0.5 \%)$ were added to all wells. The plates were examined for color change after 3 hours. To confirm the MIC and minimum bactericidal concentration (MBC), $50 \mu \mathrm{l}$ were taken from wells with no visible growth and inoculated in Müller-Hinton agar. After 24 hours of aerobic incubation at $37{ }^{\circ} \mathrm{C}$, the numbers of viable microorganisms was determined.

The MBC was then recorded as the lowest concentration that killed at least $99.99 \%$ of bacteria (13). All experiments were repeated at least three times. The same concentrations of ethanol and bacteria without the extracts were used as the negative and positive controls, respectively. 


\section{RESULTS}

Table 1 presents the MIC and MBC values of the methanolic and aqueous extract of $C$. sativus stigma against the tested bacteria. The MIC of the methanolic extract of $C$. sativus stigma was $320 \mu \mathrm{g} / \mathrm{ml}$ against $P$. aeruginosa, $S$. pyogenes, $E$. coli and $K$. pneumonia and $160 \mu \mathrm{g} / \mathrm{ml}$ against S. aureus and Enterococcus. The MBC of this extract was $160 \mu \mathrm{g} / \mathrm{ml}$ against Enterococcus and 320 $\mu \mathrm{g} / \mathrm{ml}$ against other bacteria.

The MIC of the aqueous extract of $C$. sativus was $320 \mu \mathrm{g} / \mathrm{ml}$ or higher against all tested bacteria except for E. coli $(160 \mu \mathrm{g} / \mathrm{ml})$.

Table 1- MIC and MBC of the methanolic and aqueous extracts of $C$. sativus stigma

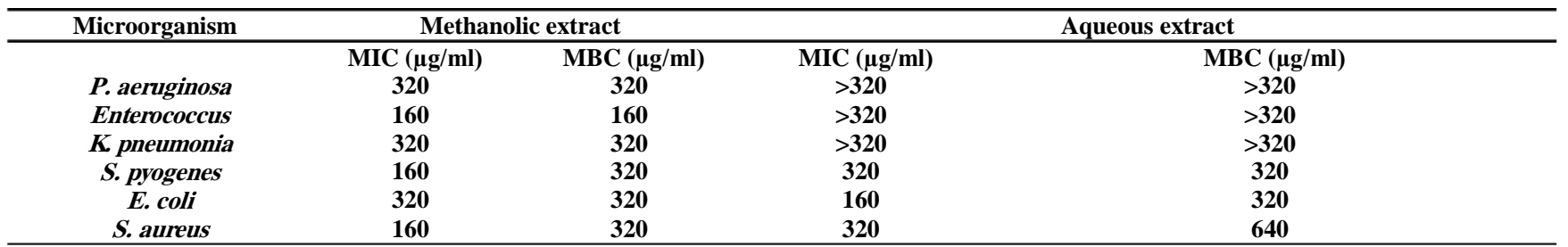

Table 2 shows the MIC and MBC values of the methanolic and aqueous extracts of $C$. cassia against the tested bacteria. The MIC of the methanolic extract of $C$. cassia was 80 $\mu \mathrm{g} / \mathrm{ml}$ against Enterococcus, K. pneumonia and E. coli and $160 \mu \mathrm{g} / \mathrm{ml}$ against $P$. aeruginosa, $S$. pyogenes and $S$. aureus. According to the results, $P$. aeruginosa, Enterococcus, $S$. pyogenes, and $S$. aureus were resistant to the aqueous extract of $C$. cassia (Table 2).

Table 2- MIC and MBC values of the methanolic and aqueous extracts of $C$. cassia

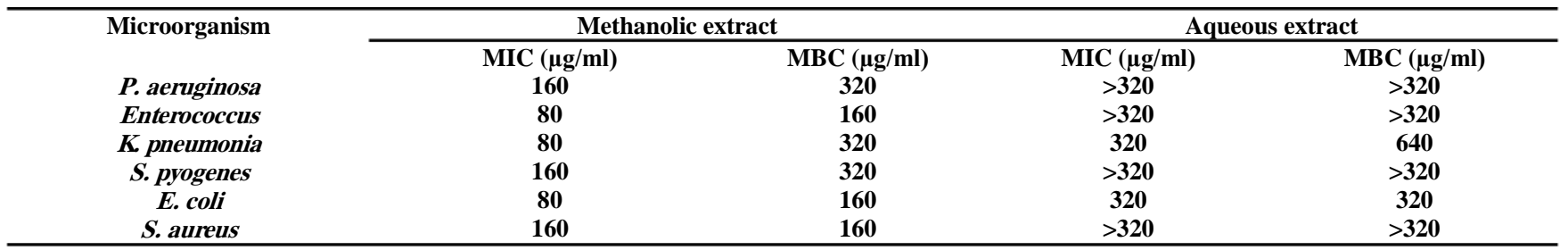

\section{DISCUSSION}

Extensive antibiotic use over the years has led to the emergence and spread of antibiotic-resistant bacterial strains. Plantderived antimicrobial compounds with antibacterial properties could be suitable alternatives to antibiotics for treatment of infections caused by antibiotic-resistant bacteria. In this study, we examined the inhibitory activity of $C$. sativus stigma and $C$. cassia extracts against some Gram-positive and Gram-negative bacteria. The results showed that both plant extracts exhibit varying degree of inhibitory effects on the clinically isolated bacteria. The MIC of the methanolic and aqueous extracts of $C$. sativus stigma against $E$. coli was $320 \mu \mathrm{g} / \mathrm{ml}$ and $160 \mu \mathrm{g} / \mathrm{ml}$, respectively. In a previous study, the MIC of $C$. sativus stigma extract against $P$. aeruginosa and E. coli was $300 \mu \mathrm{g} / \mathrm{ml}$ and $500 \mu \mathrm{g} / \mathrm{ml}$, respectively. In addition, the MIC and MBC of the extract against S. aureus was $200 \mu \mathrm{g} / \mathrm{ml}$ and $300 \mu \mathrm{g} / \mathrm{ml}$, respectively (14). However, in our study, the MIC of the methanolic and aqueous extracts of $C$. sativus stigma against S. aureus was $160 \mu \mathrm{g} / \mathrm{ml}$ and $320 \mu \mathrm{g} / \mathrm{ml}$, respectively.

In a study by Pintado et al., the MIC of safranal against $S$. aureus and E. coli was 4 $\mathrm{mg} / \mathrm{ml}$ (15). Methanolic extracts of various Crocus spp. were found to have significant inhibitory activity against different bacteria (16). The antimicrobial properties of saffron extracts are mainly attributed to safranal and crocin (17), while cinnamaldehyde is the main active antibacterial constituent of cinnamon (18). In our study, the MIC of the methanolic extract of $C$. cassia was $160 \mu \mathrm{g} / \mathrm{ml}$ against $P$. aeruginosa. Inconsistent with this finding, Gupta et al. claimed that $P$. aeruginosa was resistant to $C$. cassia extract. The MIC values reported by Gupta et al. for $S$. aureus (62.5 $\mathrm{mg} / \mathrm{ml})$ and E. coli $(1000 \mathrm{mg} / \mathrm{ml})$ were also 
significantly higher than the values we found in the present study (18). In another study, the ethanolic extracts of cinnamon and turmeric effectively inhibited growth of Bacillus subtilis and E. coli, which implies that the extracts could be equally effective against both Gram-negative and Gram-positive bacteria (19).

In our study, the methanolic extract of $C$. sativus was more effective than the aqueous extract against growth of $S$. pyogenes and $S$. aureus. Given the results of the MIC assay, it can be concluded that the methanolic extract of $C$. cassia was more effective than the methonalic extract of $C$. sativus against Enterococus, $K$. pneumonia and E. coli.

\section{CONCLUSION}

The extracts of $C$. sativus and $C$. cassia exhibit promising antibacterial activities against clinical isolates of $S$. aureus, E. coli, $P$.

\section{REFERENCES}

1. Soniya M, Kuberan T, Anitha S, Sankareswari P. In vitro antibacterial activity of plant extracts against Gram positive and Gram negative pathogenic bacteria. International Journal of Microbiology and Immunology Research. 2013; 2(1): $1-5$.

2. Bidlack WR, Omaye ST, Meskin MS, Topham DK. Phytochemicals as bioactive agents: CRC press. 2000.

3. Djeussi DE, Noumedem JA, Seukep JA, Fankam AG, Voukeng IK, Tankeo SB, et al. Antibacterial activities of selected edible plants extracts against multidrug-resistant Gram-negative bacteria. BMC Complement Altern Med. 2013; 13: 164. doi: 10.1186/1472-6882-13-164.

4. Al-Mariri A, Safi M. In vitro antibacterial activity of several plant extracts and oils against some gram-negative bacteria. Iran J Med Sci. 2014; 39(1): 36-39.

5. Sumitra C, Yogesh B. Extraction of active compounds of some medical plants. African journal of Biotechnology. 2010;9:3210-7.

6. Vahidi H, Kamalinejad M, Sedaghati N. Antimicrobial properties of Croccus sativus L. Iranian Journal of Pharmaceutical Research. 2002; 1(2): 33-5.

7. Okmen G, Kardas S, Bayrak D, Arslan A, Cakar h. the antibacterial activities of crocus sativus against mastitis pathogens and its antioxidant activities. world journal of pharmacy and pharmaceutical sciences. 2016; 5(3):146-156.

8. Zhang Y, Liu X, Wang Y, Jiang P, Quek S. Antibacterial activity and mechanism of cinnamon essential oil against Escherichia coli and Staphylococcus aureus. Food Control. 2016; 59: 282-9.

9. Buru AS, Pichika MR, Neela V, Mohandas K. In vitro antibacterial effects of Cinnamomum extracts on common bacteria found in wound infections with emphasis on methicillin-resistant Staphylococcus aureus. Journal of ethnopharmacology. 2014; 153(3): 587-95.

10. Li Y-q, Kong D-x, Wu H. Analysis and evaluation of essential oil components of cinnamon barks using $G C-M S$ and FTIR spectroscopy. Industrial Crops and Products. 2013; 41: 269-78. aeruginosa, Enterococcus, $S$. pyogenes and $K$. pneumoniae. Based on the results of the MIC assay, it can be inferred that the methanolic extracts are generally more effective than the aqueous extract against the tested pathogens. Our results suggest that the extract of these plants can be further exploited as potential antibacterial agents against multidrug-resistant bacteria.

\section{ACKNOWLEDGEMENTS}

The authors gratefully acknowledge the assistance from the Department of Medical Microbiology and Faculty of Paramedical Sciences of Mashhad University of Medical Science, Iran.

\section{CONFLICT OF INTEREST}

All authors declare that there is no conflict of interest regarding the publication of this article.

11. Clinical and Laboratory Standard Institute(CLSI). Performance Standards for Antimicrobial Susceptibility Testing: Twenty First Informational Supplement. CLSI document M100-S21. 2011.

12. Sette L, Passarini MR, Delarmelina C ,Salati F, Duarte MC. Molecular characterization and antimicrobial activity of endophytic fungi from coffee plants. World Journal of Microbiology and Biotechnology. 2006; 22(11): 1185-95.

13. Asgarpanah J, Darabi-Mahboub E, Mahboubi A, Mehrab R, Hakemivala M. In-Vitro Evaluation of Crocus Sativus $L$. Petals and Stamens as Natural Antibacterial Agents Against Food-Borne Bacterial Strains. Iranian Journal of Pharmaceutical Sciences. 2013; 9(4): 69-82.

14. Parray JA, Kamili AN, Hamid R, Reshi ZA, Qadri RA. Antibacterial and antioxidant activity of methanol extracts of Crocus sativus L. cv. Kashmirianus. Frontiers in Life Science. 2015; 8(1): 40-6.

15. Pintado C, de Miguel A, Acevedo O, Nozal L, Novella JL, Rotger R. Bactericidal effect of saffron (Crocus sativus $L$ (.on Salmonella enterica during storage. Food Control. 2011; 22(3): 638-42.

16. Acar G, Dogan NM, Duru ME, Kivrak I. Phenolic profiles antimicrobial and antioxidant activity of the various extracts of Crocus species in Anatolia. African Journal of Microbiology Research. 2010; 4(11): 1154-61.

17. Carmona M, Zalacain A, Salinas M, Alonso G. A new approach to saffron aroma. Critical Reviews in Food Science and Nutrition. 2007; 47(2): 145-59.

18. Gupta C, Garg AP, Uniyal RC, Kumari A. Comparative analysis of the antimicrobial activity of cinnamon oil and cinnamon extract on some food-borne microbes. African Journal of Microbiology Research. 2008; 2(9): 247-51.

19. Mukhtar S, Ghori I. Antibacterial activity of aqueous and ethanolic extracts of garlic, cinnamon and turmeric against escherichia coli ATCC 25922 and bacillus subtilis DSM 3256. International Journal of Applied Biology and Pharmaceutical Technology. 2012; 3(2): 131-136. 